\title{
SENGKETA TANAH WAKAF DAN STRATEGI PENYELESAIANNYA
}

\author{
Nur Fadhilah \\ Sekolah Tinggi Agama Islam Negeri Tulungagung \\ Email:nurfafiya@yahoo.co.id
}

\begin{abstract}
Abstrak
People have less attention to the administrative regulations in implenting Wakaf in particularly those who are practicing the wakaf. As a result, most of wakaf statuses are unclear juridically as well as administratively. The condition may lead to unappropriate usage of the wakaf itself in term of its law substance and the aim of the practice. In order to anticipate and to minimize the undesirable impact of wakaf land conflict which is commonly happended, it is necessary to point out the triggering factors of the conflict and its solving strategies. This paper will discuss several factors contributing the wakaf conflict based on conflict resolution theory of Ralf Dahrendorf and its solving strategies based on wakaf regulations poiont of views. The discussion concludes that resources, interest or need, values, relationship and information including structure are among the triggereing factors of the conflict. While, bringing the case to the court is the last strategy to solve the conflict.

Masyarakat belum sepenuhnya memberikan perhatian terhadap peraturan-peraturan dalam pelaksanaan wakaf terutama bagi mereka yang melakukan atau memberikan wakaf. Hal ini menyebabkan ketidakjelasan dari status wakaf itu sendiri baik secara yuridis maupun administratif. Kondisi ini juga bisa menyebabkan terjadinya kesalahan penggunaan wakaf dari aspek subtansi hukum maupun tujuan dari wakaf itu sendiri.Untuk mengantisipasi dan meminimalisir dampak-dampak yang tidak baik dari konflik wakaf tanah yang sering terjadi, maka penting untuk mengkaji faktor-faktor pemicu serta strategi penyelasaian dari konflik tersebut. Tulisan ini akan mendiskusikan bebrapa faktor yang menyebabkan konflik wakaf berdasarkan teori resolusi konflik Ralf Dahrendorf serta strategi penyelesainnya berdasarkan sudut pandang peraturan-peraturan wakaf. Kajian dari tulisan ini menyimpulkan bahwa resourses, kepentingan atau kebutuhan, nilai, hubungan dan informasi termasuk struktur adalah beberapa faktor pemicu dari konflik wakaf. Membawa permasalahan atau konflik wakaf ke pengadilan adalah strategi terakhir dari penyelesaian konflik tersebut.
\end{abstract}

Kata kunci: Tanah wakaf, Konflik wakaf, Strategi.

Bagi sebagian besar rakyat Indonesia, tanah menempati kedudukan penting dalam kehidupan sehari-hari. Terlebih lagi bagi rakyat pedesaan yang pekerjaaan pokoknya bertani, berkebun atau berladang. Penguasaan tanah di pedesaan menyangkut berbagai aspek seperti aspek ekonomi, demografi, hukum, politik dan sosial. Panda- ngan ekonomi melihat tanah sebagai faktor produksi. Tetapi karena faktor produksi yang berupa tanah makin lama makin merupakan barang yang langka, maka perbandingan jumlah manusia dengan luas tanah pertanian menjadi penting. Hal ini termasuk sudut pandang demografis. Sedangkan pandangan hukum lebih melihat 
kepadapolahakdankewajibanparapemakai tanah, atau kerangka (formal maupun informal) yang mengatur segala aktivitas ekonomi yang ada hubungannya dengan tanah, namun untuk memungkinkan agar segala peraturan ditaati oleh semua warga masyarakat diperlukan adanya aparatur organisasi yang dapat memaksakan peraturan itu. Artinya, diperlukan adanya kekuasaan. Maka di sinilah terkait sudut pandang politik. Dari keempat sudut pandang di atas (ekonomi, demografi, hukum dan politik), masyarakat dapat dipetakan bagaimana susunan lapisan-lapisannya, maka terkaitlah dalam hal ini sudut pandang sosiologis. ${ }^{1}$

Di antara hubungan manusia dengan tanah yang bersifat religius terdapat suatu lembagahak atas tanah yang disebut dengan tanah wakaf. Wakaf yang terambil dari kata kerja bahasa Arab waqafa, menurut bahasa berarti menahan atau berhenti. Dalam hukum Islam wakaf berarti menyerahkan suatu hak milik yang tahan lama zatnya kepada seseorang atau Nadzir baik berupa perorangan maupun berupa badan pengelolaan dengan ketentuan bahwa hasil atau manfaatnya digunakan untuk hal-hal yang sesuai dengan ajaran syariat Islam. Harta yang telah diwakafkan, keluar dari hak milik yang mewakafkan, dan bukan pula menjadi hak milik nadzir atau tempat menyerahkan, tetapi menjadi hak Allah dalam pengertian hak masyarakat umum.

Dalam pelaksanaan wakaf, ketentuanketentuan administratif dalam Peraturan Pemerintah Nomor 28 Tahun 1977 tentang Perwakafan Tanah Milik, Instruksi Presiden Nomor 1 Tahun 1991 tentang Kompilasi Hukum Islam khususnya Buku III yang mengatur Hukum Perwakafan dan Undangundang Nomor 41 Tahun 2004 tentang Wakaf belum sepenuhnya mendapat perhatian masyarakat pada umumnya, dan

1 Gunawan Wiradi, Pola Penguasaan Tanah dan Reforma Agraria, dalam Sediono M.P. Tjondronegoro \& Gunawan Wiradi (penyunting). Dua Abad Penguasaan Tanah: Pola Penguasaan Tanah Pertanian dari Masa ke Masa (Jakarta: Yayasan Obor Indonesia dan PT Gramedia,1984), h. 286-287. khususnya pihak yang berwakaf. Pada diri wakif yang amat menonjol adalah sisi ibadah dari praktek wakaf. Oleh karena itu, wakif tidak merasa perlu untuk dicatat atau diadministrasikan. Dengan demikian, perwakafan itu dilakukan atas dasar keikhlasan dan keridoan semata serta menurut tata cara adat setempat tanpa didukung data otentik dan surat-surat keterangan, sehingga secara yuridis administratif status wakaf banyak yang tidak jelas.

Dalam kondisi di mana nilai dan penggunaan tanah semakin besar dan meluas seperti sekarang ini, maka tanah wakaf yang tidak jelas secara hukum tersebut, telah banyak mengundang kerawanan dan memudahkan terjadinya penyimpangan dari hakekat hukum dan tujuan perwakafan, seperti adanya tanah wakaf yang tidak lagi diketahui keadaannya, adanya tanah wakaf yang seolaholah telah menjadi milik ahli waris wakif atau nadzirnya, adanya sengketa dan gugatan terhadap tanah-tanah wakaf dan berbagai kasus tanah wakaf lainnya. Dalam rangka mengantisipasi dan meminimalisir timbulnya sengketa tanah wakaf maka perlu dikemukakan pembahasan terkait dengan faktor pemicu terjadinya sengketa dan strategi penyelesaiannya. Adapun metode pembahasan yang akan digunakan adalah sebagai berikut; 1) Faktor pemicu terjadinya sengketa tanah wakaf akan ditinjau dari sudut pandang teori penyelesaian konflik (conflict resolution theory) Ralf Dahrendorf yang meliputi: resources; interest atau needs; values; relationship dan information; dan structure. 2) Strategi penyelesaian sengketa wakaf akan ditinjau dari peraturan perundang-undangan tentang wakaf yang terdiri dari: Peraturan Pemerintah Nomor 28 Tahun 1977 tentang Perwakafan Tanah Milik, Instruksi Presiden Nomor 1 Tahun 1991 tentang Kompilasi Hukum Islam khususnya Buku III yang mengatur Hukum Perwakafan dan Undang-undang Nomor 41 Tahun 2004 tentang Wakaf. 


\section{Sekilas Tentang Wakaf}

Wakaf adalah suatu lembaga sosial Islam yang lazim dipahami dengan menahan sesuatu benda untuk diambil manfaatnya dan dilembagakan guna kepentingan umum. Ada tiga sumber pengetahuan yang harus dikaji untuk memahami lembaga ini, yaitu²: a) ajaran Islam yang bersumber dari al-Qur'an dan al-Hadits serta ijtihad para mujtahid; b) peraturan perundang-undangan baik yang dikeluarkan oleh Pemerintah Belanda maupun yang dkeluarkan oleh Pemerintah Indonesia; c) wakaf yang tumbuh dalam masyarakat. Hal senada juga dikemukakan oleh Juhaya S. Praja ${ }^{3}$, bahwa kajian wakaf sebagai pranata sosial merujuk kepada tiga corpus: a) wakaf sebagai lembaga keagamaan; b) wakaf sebagai lembaga yang diatur oleh negara; c) wakaf sebagai lembaga kemasyarakatan atau suatu lembaga yang hidup dalam masyarakat.

Wakaf berasal dari kata waqafa (menahan, berhenti, diam di tempat, tetap berdiri). Kata ini sama artinya dengan habasa. Adapun menurut syara' wakaf adalah menahan dzat (asal) benda dan mempergunakan hasilnya, artinya menahan benda dan mempergunakan manfaatnya di jalan Allah. ${ }^{4}$

Wahbah al-Zuhaily ${ }^{5}$ mengemukakan pengertian wakaf menurut beberapa ulama sebagai berikut: 1) Pengertian perta$m a$, menurut Abu Hanifah wakaf adalah menahan suatu benda yang menurut hukum tetap milik wakif dalam rangka mempergunakan manfaatnya untuk kebaikan. Berdasarkan definisi ini maka pemilikan harta wakaf tidak lepas dari tangan wakif bahkan ia dibenarkan menariknya kembali dan boleh menjualnya; 2) Pengertian kedua, menurut Jumhur wakaf adalah menahan suatu benda yang mung-

2 Muhammad Daud Ali, Sistem Ekonomi Islam: Zakat dan Wakaf (Jakarta: Universitas Indonesia Press, 1988), h. 77.

3 Juhaya S. Praja, Perwakafan di Indonesia: Sejarah, Pemikiran, Hukum dan Perkembangannya. (Bandung: Yayasan Piara, 1995), h. 1.

4 Sayid Sabiq, Figh al Sunnah (Jilid 3. Beirut: Dar al Fikr, 1983), h. 378.

5 Wahbah Al-Zuhaily, al Figh al Islamiy wa Adillatuh (Jilid VIII. Damsyiq: Dar al Fikr, 1989), h. 153-156. kin diambil manfaatnya (hasilnya) sedang bendanya tidak terganggu. Menurut Jumhur hak pemilikan atas harta wakaf itu sudah lepas dari orang yang berwakaf dan telah menjadi milik Allah SWT. Dengan demikian wakaf bersifat kekal, selama harta tersebut tetap utuh. Suatu wakaf tidak boleh bersifat sementara dan ditarik kembali; 3) Pengertian ketiga, menurut Malikiyah wakaf adalah perbuatan wakif yang menjadikan manfaat hartanya untuk digunakan oleh mustahiq (penerima wakaf). Dengan kata lain, pemilik harta menahan benda itu dari penggunaan secara pemilikan, tetapi membolehkan pemanfaatan hasilnya untuk tujuan kebaikan, yaitu pemberian manfaat benda yang diwakafkan itu sedangkan benda yang diwakafkan tetap menjadi milik wakif. Masa berlakunya bukan untuk selama-lamanya melainkan hanya untuk jangka waktu tertentu sesuai dengan keinginan wakif ketika mengucapkan shighat wakafnya dan karenanya tidak disyaratkan sebagai wakaf kekal (selamanya).

Adapun unsur-unsur atau rukun wakaf menurut sebagian besar ulama adalah: 1) Orang yang berwakaf (waqif). Wakif harus mempunyai kecakapan melakukan tabarru yaitu melepaskan hak milik tanpa imbangan materiil. Cakap ber-tabarru didasarkan pertimbangan akal yang sempurna pada orang yang telah mencapai umur baligh dan rasyid yang mengacu pada kematangan jiwa atau kematangan akal; 2) Harta yang diwakafkan (mauquf). Mauquf dipandang sah apabila merupakan harta bernilai, tahan lama dipergunakan dan hak milik wakif. Harta wakaf dapat berupa benda tetap maupun benda bergerak; 3) Tujuan wakaf (mauquf 'alaih), tidak boleh bertentangan dengan nilai-nilai ibadah dan harus jelas peruntukannya; 4) Akad/pernyataan wakaf (shighat), dapat dikemukakan dengan tulisan, lisan atau dengan suatu isyarat yang dapat dipahami maksudnya hanya bagi orang yang tidak dapat menggunakan cara tulisan atau lisan. Dalam Pasal 6 UndangUndang Nomor 41 Tahun 2004 tentang 
Wakaf, unsur wakaf ditambah dua hal lagi yaitu: pengelola wakaf (nadzir) dan jangka waktu wakaf.

Terkait dengan perubahan benda wakaf, Ibnu Taimiyah mengemukakan dua sebab kebolehan merubah wakaf, yaitu: a) karena kebutuhan, misalnya masjid yang rusak dan tidak mungkin lagi diramaikan, maka tanahnya dijual dan harganya dipergunakan untuk membeli apa yang dapat menggantikannya; b) karena maslahah yang lebih kuat (rajih), misalnya mesjid, bila dibangun mesjid lain sebagai gantinya dan lebih layak bagi penduduk kampung, maka mesjid yang pertama dijual. ${ }^{6}$ Dengan demikian, pokok utama dalam hal mengganti dan menjual harta wakaf adalah kemaslahatan dan manfaatnya, sehingga tidak tepat jika harta wakaf yang rusak atau tidak memenuhi fungsinya lagi sebagai harta wakaf untuk tujuan tertentu, kemudian dibiarkan tanpa tindakan yang positif.

Adapun sebagai lembaga yang diatur oleh negara, pengaturan wakaf oleh negara dimulai sejak awal abad ke dua puluh yang dilakukan pihak pemerintah Kolonial Belanda dan selanjutnya mengalami perkembangan sampai tahun 2004. Regulasi wakaf pada masa kolonial mulai ditetapkan pada tahun 1905 yang kemudian direvisi beberapa kali pada tahun 1931, 1934, dan 1935. Ketentuan-ketentuan hukum wakaf secara umum hanya mengatur wewenang dan prosedur perizinan dan pendaftaran tanah wakaf serta hal-hal administratif terkait.

Regulasi wakaf pada masa kemerdekaan dapat dikemukakan sebagai berikut: 1) UU No. 5 Tahun 1960 tentang Peraturan Dasar Pokok-pokok Agraria yang secara resmi menyatakan perlindungan terhadap harta wakaf (Pasal 49 Ayat 3). Penegasan atas perlindungan tanah milik perwakafan tertuang dalam PP No. 10 Tahun 1961 tentang Pendaftaran Tanah. Peraturan ini meningkatkan penertiban sertifikasi tanah atas tanah wakaf yang telah diikrarkan, yang biasanya dipandang sah cukup hanya

6 Sayid Sabiq, Fiqh., h. 385-386. dengan ikrar lisan; 2) PP No. 28 Tahun 1977 tentang Perwakafan Tanah Milik. Peraturan ini tergolong peraturan pertama yang memuat unsur-unsur substansi dan teknis perwakafan; 3) Inpres No. 1 Tahun 1991 tentang KHI. Perluasan aturan perwakafan dalam KHI antara lain berkaitan dengan obyek wakaf dan nadzir; 4) UU No. 41 Tahun 2004 tentang Wakaf dan PP No. 42 Tahun 2006 tentang Pelaksanaan UU Wakaf. Ketentuan ini mencoba merevitalisasi institusi wakaf dengan mempertajam definisi, fungsi, cakupan, inovasi institusi, mekanisme pengawasan, serta tata kelola perwakafan.

Masalah pendaftaran atau sertifikasi objek wakaf jika ditinjau dari al-Qur'an sebagai sumber utama hukum Islam, dapat diqiyaskan pada masalah kesaksian dalam muamalah sebagaimana dalam QS. Al Baqarah (2) ayat 282. Namun demikian, dalam kitab-kitab fiqih belum dibicarakan masalah pendaftaran dan sertifikasi tanah wakaf sehingga dalam implementasinya saat ini, rumusan wakaf dalam kitab-kitab fiqih, perlu dilengkapi dengan aspek-aspek yang bersifat yuridis administratif. Hal ini dimaksudkan untuk meningkatkan kemaslahatan yang ingin dicapai oleh perbuatan wakaf itu, misalnya ketentuan tentang Akta Ikrar Wakaf/Pengganti Akta Ikrar Wakaf, sertifikat wakaf, keterlibatan saksi dalam ikrar atau penyerahan benda wakaf dan penunjukan nadzir yang dilengkapi dengan rincian tugas dan tanggungjawabnya.

Gagasan pembaharuan hukum Islam dalam bidang perwakafan di atas adalah gambaran tentang nuansa pembaharuan hukum Islam di Indonesia. Hal ini sebagaimana dikemukakan oleh Amir Syarifuddin ${ }^{7}$, bahwa reaktualisasi hukum Islam dapat dikategorikan menjadi empat, yaitu: 1)Kebijakan administratif; 2)Aturan tambahan; 3)Menempuh cara talfiq, yaitu meramu beberapa pemikiran atau hasil ijtihaddalamsuatumasalahtertentumenjadi

7 Amir Syarifuddin, Pembaharuan Pemikiran dalam Hukum Islam (Padang: Angkasa Raya, 1993) h.e121.ith 
satu bentuk yang kelihatannya seperti baru; 4)Reinterpretasi dan reformulasi, yaitu mengkaji ulang dalil dan bagian-bagian figih yang tidak aktual lagi dalam situasi dan kondisi tertentu, kemudian disusun penafsiran dan formulasi baru.

Dalam masalah perwakafan, umat Islam Indonesia mayoritas berafiliasi kepada mazhab Syafi'i, sedangkan dalam pembaharuan hukum Islam, digunakan pemikiran para ulama fiqih mazhab yang lain, misalnya konsep wakaf dalam PP Nomor 28 Tahun 1977 dan KHI bersifat permanen atau "selama-lamanya" yang diambil dari pemikiran mazhab Syafi'i, adapun UU Wakaf menentukan adanya jangka waktu yang merupakan pendapat mazhab Maliki, begitu pula dalam hal mengganti atau menjual harta wakaf, menurut mazhab Syafi'i tidak diperbolehkan, namun dalam peraturan perundang-undangan tentang perwakafan hal ini diperbolehkan dengan mempertimbangkan aspek kemaslahatan dan manfaat.

Keberadaan wakaf juga tidak dapat dilepaskan dari hukum adat di Indonesia, karena perbuatan wakaf sudah lama menjadi kebiasaan dalam kehidupan sehari-hari masyarakat Indonesia. Di kalangan ahli hukum Belanda, lembaga wakaf dikenal dengan istilah Vrome Stichting, sebagaimana disertasi Koesoema Atmadja pada Universitas Leiden dengan judul Mohammedaansche Vrome Stichtingen (1922), yang menyatakan bahwa meskipun wakaf didasarkan pada ketentuan dan ajaran agama Islam akan tetapi lembaga ini sudah dikenal di Indonesia sebelum kedatangan agama Islam, dengan adanya beberapa jenis wakaf berikut inis: 1)Pada suku Badui di Cibeo (Banten Selatan) dikenal Huma Serang, yaitu ladang-ladang yang tiap tahun dikerjakan secara bersama-sama dan hasilnya dipergunakan untuk kepentingan bersama; 2)Di pulau Bali ada semacam lembaga wakaf dimana terdapat tanah dan

8 Abdurrahman, Masalah Perwakafan Tanah Milik dan Kedudukan Tanah Wakaf di Negara Kita (Bandung: Citra Aditya Bakti, 1994), h. 14. barang-barang lain seperti benda-benda perhiasan untuk pesta, yang menjadi milik candi atau dewa-dewa yang tinggal di sana; 3)Di Lombok terdapat Tanah Pareman, yaitu tanah negara yang dibebaskan dari pajak landrente, kemudian diserahkan kepada desa-desa, subak, atau candi untuk kepentingan bersama.

Koesoema Atmadja dalam Abdurrahman $^{9}$ merumuskan pengertian wakaf sebagai suatu perbuatan hukum dimana suatu barang telah dikeluarkan/diambil kegunaanya dari lalu lintas masyarakat guna kepentingan orang tertentu. Perwakafan merupakan suatu perbuatan hukum tersendiri yang dipandang dari sudut tertentu bersifat rangkap, karena di satu sisi perbuatan tersebut menyebabkan objeknya memperoleh kedudukan yang khusus, sedangkan di sisi lain perbuatan tersebut menimbulkan suatu badan hukum (rechtpersoon) dalam hukum adat yang bisa ikut serta dalam kehidupan hukum sebagai subjek hukum. ${ }^{10}$

\section{Sengketa Dan Upaya Penyelesaiannya}

Konflik merupakan situasi atau kondisi adanya pertentangan atau ketidaksesuaian antara para pihak yang akan dan sedang mengadakan hubungan atau kerja sama. Pada umumnya konflik akan terjadi di mana saja sepanjang terjadi interaksi atau hubungan antara sesama manusia, baik antara individu dengan individu maupun kelompok dengan kelompok dalam melakukan sesuatu. Menurut Rachmadi Usman $^{11}$, kata conflict dan dispute keduanya mengandung pengertian tentang adanya perbedaan kepentingan di antara kedua pihak atau lebih, tetapi keduanya dapat dibedakan. Kata conflict sudah diserap ke dalam bahasa Indonesia menjadi konflik, sedangkan kata dispute dapat diterjemahkan dengan sengketa. Sebuah konflik, yakni se-

9 Abdurrahman, Masalah., h. 15.

10 B.Z.N. Ter Haar, Asas-asas dan Susunan Hukum Adat (Jakarta: Pradnya Paramita, 1983), h. 161-162.

11 Rachmadi Usman, Pilihan Penyelesaian Sengketa di Luar Pengadilan (Bandung: PT. Citra AdityáBaktì, 20013), h. 1. 
buah situasi di mana dua pihak atau lebih dihadapkan pada perbedaan kepentingan, tidak akan berkembang menjadi sengketa, apabila pihak yang merasa dirugikan hanya memendam perasaan tidak puas atau keprihatinannya. Sebuah konflik berubah atau berkembang menjadi sebuah sengketa bilamana pihak yang merasa dirugikan telah menyatakan rasa tidak puas atau keprihatinannya, baik secara langsung kepada pihak-pihak yang dianggap sebagai penyebab kerugian atau kepada pihak lain. Dengan demikian sengketa merupakan kelanjutan dari konflik, atau sebuah konflik akan berubah menjadi sengketa apabila tidak dapat diselesaikan.

Secara umum dikatakan bahwa terjadinya konflik dalam masyarakat bersumber dari persoalan-persoalan sebagai berikut ${ }^{12}$ : a) Penguasaan, pemanfaatan dan distribusi sumber daya alam yang menjadi pendukung kehidupan manusia (natural resource control and distribution); b) Ekspansi batas wilayah kehidupan suatu kelompok masyarakat (teritoriality expantion); c) Kegiatan ekonomi masyarakat (economic activities); d) Kepadatan penduduk (density of population).

Adapun menurut teori penyelesaian konflik (conflict resolution theory), akar konflik biasanya terdiri dari beberapa hal yang saling berhubungan, yaitu ${ }^{13}$ : a) masalah resources (sumber-sumber seperti: tanah, dana atau uang, perumahan); b) masalah interests atau needs (kepentingan atau kebutuhan yang berbeda); c) masalah values (nilai-nilai: agama, budaya, moral); d) masalah information (kurangnya informasi, adanya misinformasi, perbedaan interpretasi data); e) masalah relationships (hubungan individu atau pribadi); f) masalah structures (struktur kekuasaan, keti-

12 I Nyoman Nurjaya, Pengelolaan Sumber Daya Alam dalam Perspektif Antropologi Hukum (Malang: Program Magister Ilmu Hukum Program Pascasarjana Universitas Brawijaya, Arena Hukum Majalah Fakultas Hukum Universitas Brawijaya dan Penerbit Universitas Negeri Malang, 2006), h. 40.

13 Sarjita, Teknik dan Strategi Penyelesaian Sengketa Pertanahan (Yogyakarta: Tugujogja Pustaka, 2005), h. 19. dakseimbangan kekuasaan).

Oleh karena itu, dalam perspektif antropologi hukum, konflik yang terjadi dalam masyarakat dapat dikategorisasi menjadi tiga macam, yaitu' ${ }^{14}$ : a) konflik kepentingan (conflict of interests); b) konflik nilai-nilai (conflict of values); c) konflik norma-norma (conflict of norms).

Sengketa (atau konflik) akan selalu dijumpai dalam kehidupan manusia atau kehidupan bermasyarakat. Sebagai suatu fenomena sosial, keadaan ini ditegaskan oleh G. Simmel dalam Kriekhoff ${ }^{15}$ :

The individual does not attain the unity of his personality exclusively by an exhaustive harmonization,..... On the contrary, contradiction and conflict not only precede this unity but are operative in it at every moment of its existence.

Dari pernyataan di atas konsep konflik dilihat sebagai wahana yang memunculkan kekuatan integratif. Studi kepustakaan menunjukkan bahwa di kalangan ahli sosiologi (termasuk sosiologi hukum) pengkajian lebih terfokus pada istilah "konflik". Sedangkan di antara para ahli antropologi hukum terdapat kecenderungan untuk memfokus pada istilah "sengketa" atau dispute.

Nader dan Todd dalam Ihromi ${ }^{16}$ menyatakan bahwa pada dasarnya konflik-konflik yang terjadi dalam masyarakat melalui tahapan-tahapan konflik (conflict stage) sebagai berikut: a) Tahap pertama, konflik berawal dari munculnya keluhan-keluhan (grievance) dari salah satu pihak terhadap pihak yang lain (individu atau kelompok), karena pihak yang mengeluh merasa hakhaknya dilanggar, diperlakukan secara tidak wajar, kasar, dipersalahkan, diinjak harga dirinya, dirusak nama baiknya, dilukai hatinya, dan lain-lain. Kondisi awal seperti

14 I Nyoman Nurjaya, Pengelolaan., h. 41.

15 Valerine J.L. Kriekhoff, Mediasi (Tinjauan dari Segi Antropologi Hukum), dalam T.O. Ihromi (Ed.). Antropologi Hukum: Sebuah Bunga Rampai (Jakarta: Yayasan Obor Indonesia, 2001), h. 224.

16 T.O. Ihromi (Ed.), Antropologi Hukum: Sebuah Bunga Rampai (Jakarta: Yayasan Obor Indonesiaz, 2001), hitro9-210. 
ini disebut sebagai tahapan pra-konflik (preconflict stage) yang cenderung mengarah kepada konfrontasi yang bersifat monadik (monadic);b) Tahapkedua, apabilakemudian pihak yang lain menunjukkan reaksi negatif berupa sikap yang bermusuhan atas munculnya keluhan-keluhan dari pihak yang pertama, maka kondisi ini meningkat eskalasinya menjadi situasi konflik (conflict stage), sehingga konfrontasi antar pihakpihak berlangsung secara diadik (diadic); c) Tahap ketiga, apabila kemudian konflik antar pihak-pihak tersebut ditunjukkan dan dibawa ke arena publik (masyarakat), dan kemudian diproses menjadi kasus perselisihan dalam institusi penyelesaian sengketa tertentu dengan melibatkan pihak ketiga, maka situasinya telah meningkat menjadi sengketa (dispute stage), dan sifat konfrontasi antar pihak-pihak yang berselisih menjadi triadik (triadic).

Secara lebih tegas rumusan tentang sengketa dikemukakan oleh Gulliver dalam Kriekhoff ${ }^{17}$ :

No dispute exists unless and until the right claimant or someone of his behalf, actively raises the initial diagreement from the level of dyadic argument into the public arena, with the express intention of doing something about the desired claim.

Adapun cara-cara yang ditempuh untuk menyelesaikan sengketa menurut S. Roberts dalam Kriekhoff ${ }^{18}$ adalah: a) penggunaan kekerasan, yaitu langsung antar pribadi; b) melalui upacara atau ritus, misalnya upacara adat; c) mempermalukan, misalnya dengan sindiran/kiasan; d) melalui makhluk-makhluk supernatural, misalnya dengan magic; e) pengucilan; f) melalui pembicaraan, yang dapat terdiri dari: 1) pembicaraan langsung (negosiasi); 2) pembicaraan tidak langsung atau dengan bantuan pihak ketiga, baik yang bertindak sebagai penengah atau penasehat (mediasi/ mediator atau perantara/go between) maupun sebagai pihak ikut menyelesaikan (arbitrasi/ arbitration dan peradilan/adjudication).

17 Valerine J.L. Kriekhoff, Antropologi., h. 225.

18 Valerine J.L. Kriekhoff, Antropologi., h. 226.
Sementara itu Nader dan Todd dalam Ihromi ${ }^{19}$ memberikan beberapa alternatif penyelesaian sengketa yang banyak digunakan oleh masyarakat, yaitu: a) Membiarkan saja (lumping it). Pihak yang merasakan perlakuan tidak adil mengambil keputusan untuk mengabaikan saja masalah atau isu yang menimbulkan tuntutannya dan meneruskan hubungannya dengan pihak yang dirasakannya merugikan; b) Mengelak (avoidance). Pihak yang merasa dirugikan memilih untuk mengurangi hubungan-hubungan dengan pihak yang merugikannya atau untuk sama sekali menghentikan hubungan tersebut; c) Paksaan (coercion), satu pihak memaksakan pemecahan pada pihak lain secara unilateral; d) Perundingan (negotiation). Dua pihak yang berhadapan merupakan para pengambil keputusan. Pemecahan dari masalah yang dihadapi dilakukan kedua belah pihak tanpa adanya pihak ketiga yang turut campur; e) Mediasi (mediation). Adanya pihak ketiga yang membantu kedua pihak yang berselisih pendapat untuk menemukan kesepakatan; f) Arbitrasi (arbitration). Penyelesaian sengketa dilakukan oleh pihak ketiga yang keputusannya disetujui oleh pihak-pihak yang bersengketa; g) Ajudikasi (adjudication); penyelesaian oleh pihak ketiga yang memiliki kewenangan untuk campur tangan, mengambil keputusan dan melaksanakan tanpa memperhatikan persetujuan pihak-pihak yang bersengketa.

\section{Faktor Pemicu Sengketa Tanah Wakaf}

Potensi tanah wakaf Indonesia menurut data Departemen Agama (Depag) hingga September 2002 tersebar di 362.471 lokasi, seluas 1.538.198.586 meter persegi. Akan tetapi, masih banyak tanah wakaf yang belum memiliki sertifikat untuk menjelaskan posisinya sebagai tanah wakaf. Tanah wakaf yang belum bersertifikat ini menjadi salah satu kendala pendayagunaan tanah wakaf. Dari data tersebut, menurut Direktur Pengembangan Zakat dan Wakaf Departemen Agama, tanah wakaf yang ber-

19 Crqạ. Thromi (Ed.), Antropologi., h. 210-212. 
sertifikat baru mencapai 75 persen ${ }^{20}$. Pada akhir tahun 2004, potensi tanah wakaf di Indonesia mencapai 403.845 lokasi dengan luas 1.566.672.406 meter persegi. Dari jumlah di atas, tanah wakaf yang sudah bersertifikat mencapai 298.698 lokasi $(73,96 \%)^{21}$.

Kondisi di atas merupakan salah satu faktor yang melatarbelakangi terjadinya sengketa tanah wakaf, diantaranya sengketa tanah wakaf Bondo Masjid Agung Semarang. Setelah selama 19 tahun dipersengketakan bahkan sempat dikuasai kelompok lain, tanah wakaf Bondo Masjid Agung Semarang, Jawa Tengah, akhirnya kembali ke tangan Badan Kesejahteraan Masjid (BKM) Semarang. BKM adalah lembaga yang dinilai lebih berwenang mengurus tanah wakaf tersebut. Sengketa tanah wakaf berawal dari kasus tukar guling dengan swasta. Namun karena diduga sarat manipulasi, hal tersebut ditentang sejumlah kalangan muda Islam. Sejak itu, mereka melancarkan berbagai aksi demo menentang kasus ruilslag tadi. Kasus bergulir hingga akhirnya, tanah Bondo Masjid Agung Semarang sebagai tanah wakaf seluas 118 hektare dari Kerajaan Demak itu dapat kembali ke tangan BKM Semarang ${ }^{22}$.

Sementara itu di Medan, warga Medan Polonia mendatangi Gedung DPRD Kotamadya Medan, baru-baru ini. Mereka memprotes tindakan pengembang PT Anugerah Dirgantara Perkasa (ADP) yang telah merusak dan mengambil lahan tanah wakaf pekuburan untuk pembangunan real estate tanpa ganti rugi. Sebenarnya warga sudah berulangkali melaporkan kasus penyerobotan tanah wakaf tersebut ke Wali Kota

20 Republika. 23 Maret 2003. Tanah Wakaf Perlu Sertifikat. (Online) http://www.republika.co.id/kirim berita.asp?id $=156749 \&$ kat $i d=105 \&$ edisi $=$ Cetak diakses 5 April 2010.

21 Saifuddin Noorhadi, Wakaf dalam Perspektif Hukum Agraria Nasional: Kajian Teoritis ke Arah Pengelolaan dan Pendayagunaan Tanah Wakaf Bersifat Produktif-Komersial (Disertasi. Malang: Program Pascasarjana Universitas Brawijaya, 2005), h. 47.

22 Liputan 6. 6-12-2001. Tuntas, Sengketa Tanah Wakaf Masjid Agung Semarang. (Online) http://berita. liputan6.com $/$ daerah $/ 200112 / 24932 /$ class $=\% 27$ vidico $\% 27$ diakses 5 April 2010.
Medan. Bukan itu saja, mereka juga melaporkan tindakan Lurah Medan Polonia, Tatang Sukadi dan Camat Burhansyah yang telah menjual dan mengalihkan tanah wakaf pekuburan untuk pembangunan perumahan mewah kepada PT ADP ${ }^{23}$.

Ada juga sengketa tanah makam Petogogan di Kebayoran Baru, Jakarta Selatan yang masih menggantung. Sengketa tanah wakaf Wan Syarifah tersebut setelah dilakukan tukar guling dengan sebuah perusahaan swasta sempat mencuat beberapa waktu lalu. Proses tukar guling mendapat perlawanan dari ahli waris makam yang menganggapnya tidak sah $^{24}$.

Adapun kasus sengketa tanah wakaf 24.000 m2 di Desa Adisana, Kecamatan Bumiayu, Kabupaten Brebes, akhirnya ditangani polisi. Satuan Reskrim Polres Brebes yang menerima pengaduan tindak pemalsuan tanda tangan dari Pengurus Yayasan Al Kautzar, H Abdul Khodir, kemarin mulai memeriksa sejumlah saksi. Sengketa tanah antara Yayasan Al Kautzar Bumiayu dan Muhammadiyah Cabang Bumiayu bermula pada 2001 lalu ketika Muhammadiyah Cabang Bumiayu menerima surat ikrar wakaf dari dokter Lisa Maulida (25), warga asal Bumiayu yang tinggal di Bekasi. Dalam surat tersebut, Lisa mewakafkan tanah Hak Milik Nomor 229 seluas 12.000 m2 di Desa Adisana kepada Muhammadiyah Cabang Bumiayu. Upaya sertifikasi pembagian tanah ternyata mengalami hambatan di Badan Pertanahan Nasional (BPN) Brebes. Karena merasa dipersulit, pengurus Muhammadiyah $\mathrm{H}$ Abdul Karim Nagib menyampaikan masalahitu kepada Lisa. Dalam sebuah pengajian akbar di Bumiayu yang dihadiri pengurus pusat Muhammadiyah Dien Syamsudin pertengahan 2002 lalu, Lisa kemudian memberikan seluruh tanah wakaf kepada $\mathrm{Mu}-$

23 Liputan 6. 22-11-2000. Tanah Wakaf Diserobot, Gedung DPRD Didemo. (Online) http://berita.liputan6. com/ekbis $/ 200011 / 4126 /$ class $=\% 27$ vidico $\% 27$ diakses 5 April 2010.

24 Tempo Interaktif. 23 Agustus 2007. Sengketa Tanah Petogogan Masih Menggantung. (Online) http:// www.tempointeraktif.com/hg/jakarta/2007/08/23/ brk,20070823 $1066153, i_{1}, \mathrm{html}$ diakses 5 April 2010. 
hammadiyah. Selang beberapa bulan, berdirilah Pondok Pesantren Al Kautzar milik Muhammadiyah di atas tanah tersebut. Melalui rapat organisasi, Ketua Cabang Muhammadiyah $\mathrm{H}$ Sudarmo selanjutnya memberikan wewenang $\mathrm{H}$ Abdul Khodir untuk mengelola pondok tersebut.

Pada perkembangan selanjutnya, pengurus Muhammadiyah menilai, Khodir telah melampaui wewenang. Dia yang mendirikan Yayasan Al Kautsar mengklaim sebagai pemilik pesantren. Atas hal itu, Muhammadiyah melayangkan surat peringatan. Dalam waktu enam bulan terakhir, Muhammadiyah telah melayangkan tiga kali surat peringatan. Namun, hingga ketiga kalinya Abdul Khodir tidak menanggapi peringatan. Tahu-tahu, Abdul Khodir telah melaporkan kasus itu ke polisi ${ }^{25}$.

Dari beberapa sengketa tanah wakaf sebagaimana dikemukakan di atas, jika ditinjau dari sudut pandang teori penyelesaian konflik (conflict resolution theory) Ralf Dahrendorf, maka faktor penyebab atau akar konfliknya dapat dikemukakan sebagai berikut:

Pertama, masalah resources. Tanah merupakan salah satu sumber daya alam (natural resources) yang tidak dapat diperbaharui (unrenewable) dan salah satu modal yang amat vital bagi semua kegiatan produksi, baik itu tanah pertanian di pedesaan maupun tanah yang strategis di perkotaan. Oleh karena itu, tanah menempati kedudukan penting dalam kehidupan sehari-hari dan memiliki makna yang multidimensional bagi masyarakat. Sehubungan dengan hal ini, penggunaan tanah wakaf yang masih bersifat konsumtif dan belum didayagunakan secara produktif serta faktor kelangkaan dan keterbatasan lahan dibandingkan jumlah penduduk, menyebabkan pihak ahli waris wakif melakukan penyimpangan dan pelanggaran

25 Suara Merdeka. 31 Mei 2005. Kasus Sengketa Tanah Wakaf Muhammadiyah Diusut. (Online) http://www.suaramerdeka.com/harian /05 05/ 31/pan11.htm diakses 5 April 2010. terhadap tanah yang sudah diwakafkan, baik itu dengan cara menjual ataupun dengan meminta kompensasi sejumlah uang pada nadzir.

Banyak faktor yang mendorong seseorang untuk tidak mengakui adanya ikrar wakaf atau untuk menarik kembali harta yang telah diwakafkan, baik oleh yang mewakafkan sendiri, maupun oleh ahli warisnya. Di antaranya, makin langkanya tanah, makin tingginya harga, menipisnya kesadaran beragama, dan bisa jadi juga disebabkan orang yang berwakaf telah mewakafkan seluruh atau sebagian besar dari hartanya, sehingga keturunannya merasa kehilangan sumber rezeki dan menjadi terlantar. Praktek wakaf yang tidak memperhitungkan sumber rezeki bagi keturunan yang menjadi tanggung jawabnya, bisa menjadi musibah dan malapetaka bagi generasi yang ditinggalkan. Oleh sebab itu, dijumpai ahli waris yang mengingkari adanya ikrar wakaf dari orang tuanya, tidak mau menyerahkan tanah wakaf kepada nadzir yang ditunjuk, atau sama sekali tidak mau memberitahukan kepada petugas adanya ikrar wakaf yang didengarnya dari orang tuanya. Di samping faktor-faktor tersebut di atas, tidak mengakui adanya ikrar wakaf bisa jadi juga disebabkan karena sikap serakah ahli waris, atau karena memang sama sekali tidak mengetahui adanya ikrar wakaf, karena tidak pernah diberitahu oleh orang tuanya.

Kedua, masalah interest atau needs (kepentingan atau kebutuhan yang berbeda). Salah satu sengketa tanah wakaf di atas disebabkan adanya benturan kepentingan antara pihak pengembang untuk membangun pemukiman dalam rangka memenuhi kebutuhan papan bagi masyarakat dengan kepentingan untuk tetap melestarikan dan mengekalkan tujuan, fungsi, dan peruntukan tanah wakaf sebagai makam. Ada juga sengketa tanah wakaf yang disebabkan adanya benturan kepentingan antara ahli waris wakif yang merasa berhak atas tanah yang sudah diwakafkan dengan pihak nadzir yang ber- 
kepentingan menjaga fungsi dan peruntukan tanah wakaf sebagai tempat ibadah atau mushalla.

Pertambahan pendudukterutamadikota, memicu pemerintah untuk menata ulang rencana tata ruang/wilayah (zoning) sesuai kebutuhan masyarakat. Pembangunan untuk kepentingan umum sebagaimana rinciannya tertulis pada Kepres Nomor 36 Tahun 2005 tentang Pengadaan Tanah bagi Pelaksanaan Pembangunan untuk Kepentingan Umum Pasal 5 sering terkait dengan desakan penggantian (tukar guling), penukaran, penjualan, dan alih fungsi tanah wakaf. Hal ini sesuai maslahat harus dibuka koridor yang menyangkut tanggung jawab nadzir walaupun dengan cara amat ketat dalam hukum positif harus diatur. ${ }^{26}$

Terkait dengan perubahan, penukaran, dan penjualan benda wakaf dalam hukum Islam dapat dikemukakan beberapa pendapat sebagai berikut; 1) Ibnu Qudamah, salah seorang ulama mazhab Hanbali dalam kitab al Mughni menyatakan bahwa apabila harta wakaf mengalami rusak sehingga tidak dapat memberi manfaat sesuai dengan tujuannya, hendaklah dijual saja, kemudian harga penjualannya dibelikan barang lain yang akan mendatangkan manfaat sesuai dengan tujuan wakaf dan barang yang dibeli itu berkedudukan sebagai harta wakaf seperti semula. 2) Ijtihad Umar bin Khattab r.a. telah mengganti masjid Kufah dengan masjid yang baru dan tempatnya pun oleh Umar bin Khattab dipindah ke tempat yang baru, sebab tempat yang lama telah dijadikan pasar sebagai tempat jual beli umum. ${ }^{27}$ 3) Ibnu Taimiyah mengemukakan 2 sebab kebolehan merubah wakaf, yaitu: a) karena kebutuhan mendesak, misalnya masjid yang rusak dan tidak mungkin lagi diramaikan, maka tanahnya dijual dan harganya dipergunakan untuk membeli apa yang dapat menggantikannya; b) karena maslahah yang lebih kuat (rajih), misalnya

26 Noorhadi, Op.cit. hlm. 37.

27 Abdul Ghafur Anshari, Hukum dan Praktik Perwakafan di Indonesia, (Yogyakarta: Pilar Media, 2005), h. 36. mesjid yang sudah tidak layak guna bagi kaum muslimin setempat, maka boleh dijual dan digunakan untuk membangun masjid yang baru, sehingga kaum muslimin dapat menggunakan dan memakmurkannya dengan maksimal. ${ }^{28}$

Dari pendapat Ibnu Qudamah, ijtihad Umar bin Khattab, dan pendapat Ibnu Taimiyah bahwa menjual, menukar, atau merubah harta wakaf diperbolehkan dan diperkenankan asal penjualan, penukaran atau perubahannya digunakan lagi sebagai harta wakaf. Dengan demikian, pokok utama dalam hal mengganti dan menjual harta wakaf adalah kemaslahatan dan manfaatnya, sehingga tidak tepat jika harta wakaf yang rusak atau tidak memenuhi fungsinya lagi sebagai harta wakaf untuk tujuan tertentu, kemudian dibiarkan tanpa tindakan yang positif.

Dalam peraturan perundang-undangan dimungkinkan adanya perubahan benda wakaf yang diatur dalam PP Nomor 28 Tahun 1977 Pasal 11 dan UU Nomor 41 Tahun 2004 Pasal 41. Pada waktu yang lampau, perubahan status tanah yang diwakafkan dapat dilakukan begitu saja oleh nadzirnya tanpa alasan-alasan yang meyakinkan. Hal-hal yang demikian ini sudah barang tentu akan menimbulkan reaksi masyarakat terutama dari mereka yang langsung berkepentingan dengan perwakafan tanah tersebut. Dalam peraturan perundang-undangan diadakan pembatasan-pembatasan yang ketat dengan terlebih dahulu mendapat izin dari Menteri Agama. Dengan cara ini, diharapkan dapat dihindarkan praktek-praktek yang merugikan perwakafan. Untuk kepentingan administrasi pertanahan, perubahan status wakaf harus didaftarkan pada pejabat yang berwenang.

Ketiga, masalah values (nilai-nilai: agama, budaya, moral, dan sebagainya). Salah satu faktor penyebab sengketa tanah wakaf pada dasarnya berawal dari tindakan ahli waris wakif yang menjual sebagian 28 Sayid Sabiq, Fiqh., h. 385-386.

(n) nitro $^{\text {PDF }}$ professional 
tanah yang sudah diwakafkan oleh orang tuanya, meskipun tanah wakaf tersebut sudah mempunyai AIW (Akta Ikrar Wakaf). Dalam hal ini terjadi benturan nilai agama-untuk tetap menggunakan dan memanfaatkan tanah wakaf sesuai dengan fungsi dan peruntukannya-dengan motivasi ekonomi dari ahli waris wakif, mengingat nilai jual (exchange value) dari tanah yang semakin tinggi. Sedangkan faktor penyebab yang lain adalah tidak adanya bukti otentik dan dokumen tertulis terkait dengan tanah wakaf, sehingga ahli waris wakif merasa berhak atas tanah tersebut. Dalam hal ini faktor penyebab sengketa adalah benturan antara nilai agamabahwa wakaf telah sah secara agama jika telah memenuhi syarat-syarat yang ditentukan oleh agama meskipun tidak didaftarkan atau tidak ada AIW (Akta Ikrar Wakaf) dengan nilai hukum positif yang memerintahkan dan mengamanatkan agar wakaf tanah didaftarkan sebagaimana ditegaskan oleh PP Nomor 28 Tahun 1977 Pasal 9 dan 10, KHI Pasal 223 dan 224, UU Wakaf Pasal 32-39. Disamping itu, sengketa ini juga disebabkan adanya benturan nilai agama dan motivasi ekonomi dari ahli waris wakif.

Menurut pendapat Imam Syafii, Malik, dan Ahmad, wakaf dianggap telah terlaksana dengan adanya lafadz atau shighat, walaupun tidak ditetapkan oleh hakim. Milik semula dari wakif telah berpindah dengan terjadinya lafadz, walaupun barang itu masih berada di tangan wakif. Hanya Abu Hanifah yang berpendapat bahwa benda wakaf belum terlepas dari milik wakif, sampai hakim memberikan putusan dengan mengumumkan barang wakaf tersebut. Dengan demikian, dalam hal wakaf menurut hukum Islam tidak diperlukan banyak persyaratan menyangkut prosedur atau tata cara pelaksanaan dan pendaftaran tanah wakaf sebagaimana ditegaskan oleh peraturan perundang-undangan tentang wakaf.

Keempat, masalah relationship dan information. Hubungan kekeluargaan antara wakif dan ahli warisnya telah memicu anggapan dari pihak ahli waris bahwa tanah yang sudah diwakafkan adalah tanah warisan dari orang tuanya, sehingga ahli waris wakif merasa berhak untuk menjual tanah itu kepada pihak lain. Ada juga sengketa tanah wakaf yang berawal dari tuntutan kompensasi atas tanah wakaf dari pihak ahli waris wakif karena beranggapan bahwa tanah wakaf itu adalah warisan dari orang tuanya (wakif), padahal sejak puluhan tahun di atas tanah tersebut berdiri bangunan mushalla atau fasilitas umum yang telah digunakan dan dimanfaatkan oleh masyarakat sekitar.

Kondisi di atas dipicu oleh kurangnya informasi dan minimnya pengetahuan tentang wakaf baik menurut hukum Islam maupun peraturan perundang-undangan mengakibatkan: a) masih adanya persepsi masyarakat bahwa wakaf adalah "ibadah" sehingga merasa tidak perlu jika wakaf diketahui orang lain, ditulis, bahkan sampai harus dengan "akta"; b) masih ada jalan fikiran atau anggapan bahwa tanpa sertifikat kedudukan hukum tanah wakaf sudah cukup kuat karena selama 3040 tahun bahkan lebih tanah tersebut digunakan dan dimanfaatkan sesuai dengan fungsi dan peruntukan wakaf, tidak ada gugatan atau tuntutan dari pihak manapun. Kedua anggapan ini mendorong terjadinya penyimpangan dari hakekat hukum dan tujuan wakaf sehingga terjadi sengketa tanah wakaf.

Masyarakat dalam melakukan wakaf masih menggunakan kebiasaan-kebiasaan keagamaan, seperti kebiasaan melakukan perbuatan hukum perwakafan tanah secara lisan atas dasar saling percaya kepada seseorang atau lembaga tertentu, kebiasaan memandang wakaf sebagai amal shaleh yang mempunyai nilai mulia di sisi Allah tanpa harus melalui prosedur administratif, dan harta wakaf dianggap milik Allah semata yang siapa saja tidak akan berani mengganggu gugat tanpa seizin Allah. Tingginya kepercayaan kepada penerima amanah dalamer melakukan wakaf tanpa disertai 


\begin{tabular}{lll}
\hline PP Nomor 28 Tahun 1977 & Kompilasi Hukum Islam & UU No. 41 Tahun 2004 \\
\hline Pasal 12: & Pasal 226: & Pasal 62: \\
Penyelesaian perselisihan & Penyelesaian perselisihan & Penyelesaian sengketa \\
sepanjang yang & sepanjang yang & perwakafan ditempuh \\
menyangkut persoalan & menyangkut persoalan & melalui musyawarah untuk \\
perwakafan tanah, & benda wakaf dan & mencapai mufakat. \\
disalurkan melalui & nadzir, diajukan kepada & Apabila penyelesaian \\
Pengadilan Agama & Pengadilan Agama & sengketa sebagaimana \\
setempat sesuai dengan & setempat sesuai dengan & dimaksud pada ayat (1) \\
ketentuan peraturan & ketentuan peraturan & tidak berhasil, sengketa \\
perundang-undangan yang & perundang-undangan yang & dapat diselesaikan melalui \\
berlaku. & berlaku. & mediasi, arbitrase, atau \\
& & pengadilan.
\end{tabular}

bukti tertulis dapat mengundang terjadinya sengketa tanah di kemudian hari.

Kelima, masalah structure. Perbedaan pandangan dan persepsi antara masyarakat dan pemerintah terkait dengan pelaksanaan wakaf dapat memicu terjadinya konflik yang mengarah pada sengketa. Sejak datangnya Islam, wakaf telah dilaksanakan berdasarkan paham yang dianut oleh sebagian besar masyarakat Islam Indonesia, yaitu paham Syafiiyah dan adat kebiasaan setempat. Dalam hal ini, perbuatan mewakafkan tanah dilakukan secara lisan tanpa adanya bukti tertulis atas dasar kepercayaan. Sedangkan dalam peraturan perundang-undangan ditegaskan bahwa wakaf harus dilakukan sesuai dengan prosedur administratif meliputi tatacara perwakafan, tatacara pemberian hak, dan tatacara untuk mendapatkan kepastian hak atas tanah yang diwakafkan, dimana ketentuan ini tidak diketahui dan tidak dikenal sebelumnya oleh masyarakat.

Adanya tanah wakaf yang tidak memenuhi ketentuan administratif sebagaimana ditegaskan dalam peraturan perundang-undangan menyebabkan ketidaksamaan dan ketidakseimbangan dalam hal kepastian hukumnya jika dibandingkan dengan tanah wakaf yang mempunyai sertifikat. Tidak adanya bukti otentik dan dokumen tertulis terkait tanah wakaf dalam hal ini sertifikat wakaf, menyebabkan kedudukan tanah wakaf tidak cukup kuat secara yuridis karena tidak ada alat bukti yang merupakan jaminan bagi kepastian hukum atas tanah wakaf jika terjadi tuntutan dan gugatan dari pihak-pihak yang berkepentingan.

\section{Strategi Penyelesaian Sengketa Tanah Wakaf}

Ketentuantentang penyelesaiansengketa wakaf dalam peraturan perundang-undangan mengalami perubahan sejak dikeluarkannya UU Nomor 41 Tahun 2004 tentang Wakaf. Perubahan itu dapat dikemukakan sebagai berikut.

\section{Penyelesaian Sengketa Wakaf dalam}

\section{Peraturan Perundang-undangan}

Jika pada PP Nomor 28 Tahun 1977 dan Kompilasi Hukum Islam sengketa wakaf diselesaikan secara litigasi dengan diajukan kepada Pengadilan Agama setempat, maka padaUUNomor41 Tahun 2004 penyelesaian sengketa wakaf ditempuh secara non litigasi melalui musyawarah, jika tidak berhasil ditempuh cara mediasi. Dalam hal mediasi tidak berhasil menyelesaikan sengketa, sengketa tersebut dapat dibawa kepada badan arbitrase syariah. Dalam hal badan arbitrase syariah tidak berhasil 
menyelesaikan sengketa, sengketa tersebut dibawa ke pengadilan agama dan/atau mahkamah syar'iyyah. Penyelesaian litigasi melalui pengadilan adalah jalan terakhir yang dilakukan apabila penyelesaian di luar pengadilan atau non litigasi tidak berhasil menyelesaikan sengketa.

Dalam hal ini, peran negara dengan mengundangkan UU Nomor 41 Tahun 2004 tentang Wakaf khususnya tentang penyelesaian sengketa wakaf secara non litigasi adalah untuk menjawab tuntutan akselerasi dan dinamika masyarakat dalam memanage konflik yang volume maupun intensitasnya semakin kompleks. Negara memberikan peluang dan kesempatan kepada masyarakat untuk menyelesaikan sengketa sesuai dengan potensi-potensi yang dimiliki melalui institusi penyelesaian konflik yang bersumber dari masyarakat sendiri (folk institution).

Pasal 1338 Kitab Undang-undang Hukum Perdata (KUHPdt) menyatakan:

Semua perjanjian yang dibuat sesuai dengan undang-undang berlaku sebagai undang-undang bagi mereka yang membuatnya. Perjanjian ini tidak dapat ditarik kembali selain dengan kesepakatan kedua belah pihak atau karena alasan-alasan yang ditentukan oleh undang-undang. Perjanjian harus dilaksanakan dengan baik.

Dari ketentuan pasal tersebut, dapat dikemukakan bahwa dalam hal hukum perjanjian, hukum positif di Indonesia menganut sistem terbuka, artinya setiap orang bebas untuk membuat perjanjian apa dan bagaimanapun juga sepanjang pembuatannya sesuai dengan ketertiban umum dan atau kesusilaan. Termasuk dalam pengertian "bebas" di sini tidak saja yang menyangkut isi atau materi perjanjian, namun juga yang menyangkut cara menyelesaikan perselisihan yang terjadi atau mungkin dapat terjadi.

Sejalan dengan berlakunya asas tersebut di atas, Pasal 14 UU Nomor 14 Tahun 1970 tentang Ketentuan Pokok Kekuasaan Ke- hakiman menyatakan: (1) Pengadilan tidak boleh menolak untuk memeriksa dan mengadili sesuatu perkara yang diajukan dengan dalih bahwa hukum tidak atau kurang jelas, melainkan wajib untuk memeriksa dan mengadilinya. (2) Ketentuan dalam ayat 1 tidak menutup kemungkinan untuk melakukan usaha penyelesaian perkara perdata secara perdamaian.

Dari ketentuan yang termaktub dalam Pasal 14 ayat 2 tersebut, keberadaan lembaga yang bertujuan utuk menyelesaikan perselisihan yang terjadi di antara pihak yang mengadakan perjanjian, sepanjang hal itu disetujui oleh kedua belah pihak, secara sah diakui di negara kita.

Cara-cara penyelesaian sengketa di luar pengadilan yang menghasilkan kesepakatan dari pihak-pihak yang terlibat, jauh lebih mampu untuk mempertahankn hubungan-hubungan yang sedang berjalan maupun untuk waktu mendatang daripada prosedur menang kalah sebagaimana dalam proses penyelesaian sengketa secara litigasi. Putusan pengadilan tidak bersifat problem solving di antara pihak yang bersengketa, tetapi menempatkan kedua belah pihak pada dua sisi ujung yang saling berhadapan, yaitu menempatkan salah satu pihak kepada posisi pemenang (the winner), dan menyudutkan pihak lain sebagai pihak yang kalah (the losser). Dalam posisi ada pihak yang menang dan kalah ini, maka bukan kedamaian dan ketentraman yang timbul, melainkan pada diri pihak yang kalah, timbul dendam dan kebencian.

Ditinjau dari faktor politik dan budaya, jiwa kooperatif dalam penyelesaian sengketa lingkungan merupakan perwujudan dari sila keempat Pancasila (musyawarah untuk mufakat). Dengan demikian, penyelesaian sengketa di luar pengadilan merupakan alternatif yang paling efektif dan efisien dalam menyelesaikan sengketa atau konflik kepentingan. Para pihak yang bersengketa duduk secara bersama-sama, merumuskan jalan keluar untuk mengakhiri perbedaan kepentingan. Selain itu, cara created with

(n) nitro ${ }^{\text {PDF }^{\prime}}$ professional 
penyelesaiannya dirumuskan pula secara bersama oleh para pihak, baik dengan atau tanpa bantuan pihak ketiga.

\section{Kesimpulan}

Sebagai penutup tulisan ini dapat dikemukakan beberapa kesimpulan sebagai berikut: Pertama, Faktor-faktor pemicu terjadinya sengketa tanah wakaf jika ditinjau dari sudut pandang teori penyelesaian konflik (conflict resolution theory) Ralf Dahrendorf adalah: a) Masalah resources; b) Masalah interest atau needs (kepentingan atau kebutuhan yang berbeda); c) Masalah values (nilai-nilai: agama, budaya, moral,

\section{DAFTAR PUSTAKA}

Abdurrahman. 1994. Masalah Perwakafan Tanah Milik dan Kedudukan Tanah Wakaf di Negara Kita. Bandung: Citra Aditya Bakti.

Ali, Muhammad Daud. 1988. Sistem Ekonomi Islam: Zakat dan Wakaf. Jakarta: Universitas Indonesia Press.

Al-Zuhaily, Wahbah. 1989. al Figh al Islamiy wa Adillatuh. Jilid VIII. Damsyiq: Dar al Fikr.

Anshari, Abdul Ghafur. 2005. Hukum dan Praktik Perwakafan di Indonesia. Yogyakarta: Pilar Media.

Haar, B.Z.N. Ter. 1983. Asas-asas dan Susunan Hukum Adat. Jakarta: Pradnya Paramita

Ihromi, T.O.(Ed.). 2001. Antropologi Hukum: Sebuah Bunga Rampai. Jakarta: Yayasan Obor Indonesia.

Kriekhoff, Valerine J.L.. 2001. Mediasi (Tinjauan dari Segi Antropologi Hukum), dalam T.O. Ihromi (Ed.). Antropologi Hukum: Sebuah Bunga Rampai. Jakarta: Yayasan Obor Indonesia.

Noorhadi, Saifuddin. 2005. Wakaf dalam Perspektif Hukum Agraria Nasional: Kajian Teoritis ke Arah Pengelolaan dan Pendayagunaan Tanah Wakaf Bersifat Produktif-Komersial). Disertasi. Malang: Program Pascasarjana Universitas Brawijaya. dsb); d) Masalah relationship dan information; e) Masalah structure (struktur kekuasaan, ketidakseimbangan kekuasaan, dsb).

Kedua, Strategi penyelesaian sengketa tanah wakaf dalam peraturan perundangundangan mengalami perubahan sejak dikeluarkannya UU Nomor 41 Tahun 2004 tentang Wakaf. Pada UU Wakaf penyelesaian sengketa wakaf ditempuh secara non litigasi melalui musyawarah, jika tidak berhasil ditempuh cara mediasi. Penyelesaian litigasi melalui pengadilan adalah jalan terakhir yang dilakukan apabila penyelesaian di luar pengadilan atau non litigasi tidak berhasil menyelesaikan sengketa.

Nurjaya, I Nyoman. 2006. Pengelolaan Sumber Daya Alam dalam Perspektif Antropologi Hukum. Malang: Program Magister Ilmu Hukum Program Pascasarjana Universitas Brawijaya, Arena Hukum Majalah Fakultas Hukum Universitas Brawijaya dan Penerbit Universitas Negeri Malang (UM-Press).

Praja, Juhaya S. 1995. Perwakafan di Indonesia: Sejarah, Pemikiran, Hukum dan Perkembangannya. Bandung: Yayasan Piara.

Sabiq, Sayid. 1983. Figh al Sunnah. Jilid 3. Beirut: Dar al Fikr.

Sarjita. 2005. Teknik dan Strategi Penyelesaian Sengketa Pertanahan. Yogyakarta: Tugujogja Pustaka.

Syarifuddin, Amir. 1993. Pembaharuan Pemikiran dalam Hukum Islam. Padang: Angkasa Raya

Usman, Rachmadi. 2003. Pilihan Penyelesaian Sengketa di Luar Pengadilan. Bandung: PT. Citra Aditya Bakti.

Wiradi, Gunawan. 1984. Pola Penguasaan Tanah dan Reforma Agraria, dalam Sediono M.P. Tjondronegoro \& Gunawan Wiradi (penyunting). Dua Abad Penguasaan Tanah: Pola Penguasaan Tanah Pertanian dari Masa ke Masa. Jakarta: Yayasan Obor Indonesia dan PT Gramedia. Created with

(n) nitro $^{\text {PDF }^{\prime}}$ professional 


\section{Peraturan Perundang-undangan:}

Peraturan Pemerintah Nomor 28 Tahun 1977 tentang Perwakafan Tanah Milik

Instruksi Presiden Nomor 1 Tahun 1991 tentang Kompilasi Hukum Islam

Undang-undang Nomor 41 Tahun 2004 tentang Wakaf

\section{Sitasi dari Internet:}

Liputan 6. 22-11-2000. Tanah WakafDiserobot, Gedung DPRD Didemo. (Online) http:// berita.liputan6.com/ekbis/200011/4126/ class $=\% 27$ vidico $\% 27$ diakses 5 April 2010.

Liputan 6. 6-12-2001. Tuntas, Sengketa Tanah Wakaf Masjid Agung Semarang.
(Online)http://berita.liputan6.com/ daerah $/ 200112 / 24932 /$ class $=\% 27$ vidico \%27 diakses 5 April 2010.

Republika. 23 Maret 2003. Tanah Wakaf Perlu Sertifikat.(Online)http://www.republika. co.id/kirim_berita.asp?id=156749\&kat id $=105 \&$ edisi $=$ Cetak diakses 5 April 2010.

Suara Merdeka. 31 Mei 2005. Kasus Sengketa Tanah Wakaf Muhammadiyah Diusut. (Online) http://www.suaramerdeka. com/harian/0505/31/pan11.htm diakses 5 April 2010.

Tempo Interaktif. 23 Agustus 2007. Sengketa Tanah Petogogan Masih Menggantung. (Online) http://www.tempointeraktif.com/hg/jakarta/2007/08/23/ brk,20070823-106153,id.html diakses 5 April 2010. 